\title{
CLIMATE CHANGE IN THE ARCTIC AND IT'S GEOPOLITICAL CONSEQUENCE - THE ANALYSIS OF THE EUROPEAN UNION PERSPECTIVE
}

\author{
MICHAŁ ŁUSZCZUK \\ International Relations Department, Maria Curie Sklodowska University in Lublin, \\ Political Science Faculty, \\ Plac Litewski 3, 20-080 Lublin, Poland \\ mluszczuk@gmail.com
}

\begin{abstract}
The article presents and briefly analyses the issue of the European Union's perspective on the problems of the climate change in the Arctic region and its geopolitical consequences. Offering an overview of the main documents in this area, the article concludes that the EU policy towards the Arctic is closely related with perceiving the climate change in polar regions not only in terms of new possibilities, but also as a source of new threats for the international environment.
\end{abstract}

KEY WORDS: climate change, international relations, European Union, Arctic policy.

\section{INTRODUCTION}

Climate change has recently become a key factor determining the shape and nature of the international system, especially in terms of international security and policy-making (Busby 2007, Giddens 2009). This is particularly true in the case of the Arctic, where research, such as the Arctic Climate Impact Assessment, has forecasted air temperature rises between 4 and 7 degrees Celsius by the end of this century and climate models are already predicting ice-free Arctic Ocean during the summer months in a few decades ahead, if not earlier (ACIA 2005) - developments which open up a wide range of new opportunities and challenges, also in terms of 
international politics. Additionally, according to the U.S. Geological Survey, the region holds large oil and natural gas reserves. Melting ice cover would in the long term facilitate the exploitation of these resources (Gautier et al. 2009) and open up access to fish stocks and particularly new shipping routes, which promise shorter distances for trade between Europe and East Asia (AMSA 2009). On the other hand, the melting of the Arctic's ice cap, while increasing the region's geopolitical and geo-economic importance, significantly exacerbates its environmental fragility and threatens the traditional way of life of the indigenous population (Heinämäki 2009).

It is clear that the melting Arctic ice cap and the resulting rise in sea levels would have serious global environmental, economic, and human security implications. Besides the five Arctic countries (A5) that encircle the Arctic Ocean (United States, Canada, Russia, Norway, Denmark and Greenland), the European Union has expressed a clear interest in the region (Airoldi 2008, Łuszczuk 2010). The object of this article is to present and briefly discuss some aspects of the European Union's approach to these challenges and to the new geopolitical situation.

In November 2008, the European Commission presented a communication entitled The European Union and the Arctic Region containing a wide-ranging and comprehensive proposal for a future EU Arctic policy, which is a milestone in the EU's approach to the Arctic region. The communication clearly points that "arctic challenges and opportunities will have significant repercussions on the life of European citizens for generations to come". Therefore, the authors of the document made an attempt to set, in a coordinated and systematic fashion, the key paths for development and activities in the framework of the future EU Arctic policy. The communication indicates the following main policy objectives: (1) protecting and preserving the Arctic in unison with its population, (2) promoting the sustainable use of resources, (3) contributing to the enhanced Arctic multilateral governance (Communication 2008).

It is difficult to determine to what extent publishing the communication by the Commission is a turning point in the EU's approach to the Arctic region on the basis of the text alone, as it does not refer in broader terms to the EU's perspectives on geopolitical and geo-economic importance of the Arctic region in the flux. Firstly, it should be noticed that the Communication was a consequence of the observations expressed more broadly in the Joint Paper presented in March 2008 by the European Union foreign policy chief Javier Solana and the European Union Commissioner for External Relations Benita Ferrero-Waldner. According to this paper, entitled Climate Change and International Security, climate change should be best viewed as a threat multiplier, which exacerbates existing trends, tensions and instability. The core challenge is that the climate change threatens to overburden states and regions which are already fragile and conflict prone. It is important to recognise that the risks are not just of a humanitarian nature; they also include political and security risks 
that directly affect European interests. Moreover, in line with the concept of human security, it is clear that many issues related to the impact of the climate change on international security are interlinked, requiring comprehensive policy responses (Joint Paper 2008). As it was stressed, the EU is in a unique position to respond to the impacts of the climate change on international security, given its leading role in development and global climate policy and the wide array of tools and instruments at its disposal. Moreover, the security challenge plays to Europe's strengths, with its comprehensive approach to conflict prevention, crisis management and postconflict reconstruction, and as a key proponent of effective multilateralism (Joint Paper 2008). The authors of the Paper predict the following threats for international security system: conflict over resources, economic damage and risk to coastal cities and critical infrastructure, loss of territory and border disputes, environmentallyinduced migration, situations of fragility and radicalization, tension over energy supply and last, but not least - pressure on international governance.

In regard to the Arctic region, it is stated that the rapid melting of the polar ice cap is opening up new waterways and international trade routes. In addition, the increased accessibility of the enormous hydrocarbon resources in the Arctic region is changing the geo-strategic dynamics of the region with potential consequences for international stability and European security interests. The resulting new strategic interests are illustrated by the recent planting of the Russian flag under the North Pole. There is an increasing need to address the growing debate over territorial claims and access to new trade routes by different countries which challenge Europe's ability to effectively secure its trade and resource interests in the region and may put pressure on its relations with key partners (Joint Paper 2008). Undoubtedly, this paper should be perceived as a example of the securitization of the climate change in the Arctic region. This approach is becoming very important in next EU's documents and plans referring to the Arctic.

This part analyses the documents and declarations which can be treated as the beginning and further shaping of the EU policy towards Arctic issues. It does so in chronological sequence, in order to highlight the institutional cooperation. In October 2008, the European Parliament, answering to the growing interest in the Arctic, both in the EU and the international context adopted a resolution on Arctic governance. The resolution set out the concerns of the Parliament for the environmental, geopolitical and social consequences of the climate change in the Arctic and expressed the hope that the expected Commission communication on the Arctic would "lay the foundations for a meaningful EU Arctic policy". This document also listed the essential elements that should be addressed in the communication: (1) the state of play in relation to the climate change, and adaptation to it, in the region; (2) policy options that respect the indigenous populations and their livelihoods;

(3) the need to cooperate with our Arctic neighbours on cross-border issues, in 
particular maritime safety; and (4) options for a future cross-border political or legal structure that could grant for the environmental protection and sustainable, orderly development of the region or mediate political disagreement over resources and navigable waterways in the High North (Resolution 2008).

In November 2008, the Commission submitted to the European Parliament and the Council its communication The European Union and the Arctic region (Communication 2008), prepared by an interservice working group under the lead of the DG on External Relations. The Commission presented the genesis of its reflection on the Integrated Maritime Policy and on the assessment of the risks to security and stability brought by the climate change in the Arctic and proceeded to set out the EU interests and to propose actions for EU Member States and institutions around three main policy objectives:

(1) protecting and preserving the Arctic in unison with its population;

(2) promoting a sustainable use of resources;

(3) contributing to the enhanced Arctic multilateral governance (Communication 2008).

In the framework of each of those objectives, the communication indicated more specific policy objectives in the relevant areas, accompanied by specific proposals for action. The actions proposed under the first two objectives, although with different degrees of relevance, amplitude, concreteness and feasibility, capture to a large extent the Parliament's preoccupations. The Commission's position on governance, however, is far less bold and innovative than that of the Parliament, and explicitly anchors the proposed action to the implementation of existing obligations and the further development of a cooperative governance system with the UN Convention on the Law of the Sea (UNCLOS) at its centre (Airoldi 2010). The conclusion is also presented in a rather cautious language, reflecting the awareness that the EU has yet to establish its presence on the Arctic scene: „The suggestions contained in this Communication aim to provide the basis for a more detailed reflection. This will be useful for implementing the EU's strategic initiatives, including the Integrated Maritime Policy. The present Communication should also lead to a structured and coordinated approach to Arctic matters, as the first layer of an Arctic policy for the European Union. This will open new cooperation perspectives with the Arctic states, helping all of us to increase stability and to establish the right balance between the priority goal of preserving the Arctic environment and the need for sustainable use of resources" (Communication 2008).

In December 2008 the General Affairs and External Relations Council presented its first reaction soon after the presentation of the communication, with short conclusions of a general nature. The Council welcomed the communication as a first layer of an EU Arctic policy, noted the special role of the Arctic EU Member States and Greenland, recognized the need to act in a systematic and coordinated 
manner to address the Arctic challenges and to enhance the EU contribution to the Arctic multilateral cooperation and asked for a more detailed reflection on the proposals contained in the communication (Łuszczuk 2010).

In April 2009 the European Parliament discussed another motion for a resolution calling on the Council and the Commission to initiate international negotiations for a treaty for the protection of the Arctic, modelled on the Antarctic Treaty, and to work at a series of initiatives aiming at the sustainable development of the region. However, given serious objections by both the Council and the Commission representatives taking part in the discussion, who underlined the politically untimely and potentially counterproductive character of such a call, the Parliament voted to postpone the consideration of the motion, which was subsequently withdrawn (Luszczuk 2010).

The detailed reflection on the Commission communication was undertaken mainly in the second half of 2009, under the Swedish Presidency. The results of this work were long and detailed Council conclusions on Arctic issues, adopted by the Foreign Affairs Council in December 2009. Council conclusions are as a rule adopted by consensus. This implies that each sentence is likely to have been weighed and fine-tuned in order to arrive at formulations which would accommodate the views of all Member States, in particular of those most interested in the subject matter. The text is therefore worth a close analysis. The key sentence is possibly the initial one, where the Council ,welcomes the gradual formulation of a policy on Arctic issues to address EU interests and responsibilities, while recognising Member States' legitimate interests and rights in the Arctic" (Conclusion 2009). Several elements can be noted: the stress on the "gradual" character of the formulation, the passage from „Arctic policy”, as used on previous occasions, to the less specific ,policy on Arctic issues", the mention of EU responsibilities alongside that of its interests, and the recognition of Member States' - presumably Arctic Member States' - special position. The Council then sets out the bases on which a (rather than the) EU policy on Arctic issues should be funded : „Effective implementation by the international community of adequate measures to mitigate climate change that are required to preserve the unique characteristics of the Arctic region; Reinforced multilateral governance through strengthening and consistent implementation of relevant international, regional and bilateral agreements, frameworks and arrangements; The United Nations Convention on the Law of the Sea (UNCLOS) and other relevant international instruments; Formulating and implementing EU actions and policies that impact on the Arctic with respect for its unique characteristics, in particular the sensitivities of ecosystems and their biodiversity as well as the needs and rights of Arctic residents, including the indigenous peoples; Maintaining the Arctic as an area of peace and stability and highlighting the need for responsible, sustainable and cautious action in view of new possibilities for transport, natural resource extraction and other entrepreneurial activities linked to melting sea ice and other climate change effects" (Conclusion 2009). Here again the stress is put 
on EU responsibilities - as well as on the EU sense of responsibility in the pursuit of its interests. There is also the preoccupation to make perfectly clear the EU will to remain within and in line with the existing governance framework, particularly UNCLOS. Even when approving the three main policy objectives proposed by the Commission, the Council further qualifies the third one „Contributing to enhanced governance in the Arctic" with somewhat repetitive but obviously politically important addition ,through implementation of relevant agreements, frameworks and arrangements, and their further development" (Conclusion 2009).

Underlining that further work is needed, the conclusions continue with a long list of considerations and invitations to actions to be undertaken by priority, as necessary for the „next step towards the formulation of an overarching approach to EU policy on Arctic issues" a rather convoluted wording which seems to add an extra layer between the present situation and the possible ultimate result-EU policy. The actions listed inevitably reflect the composite, multidisciplinary nature of the subject, as well as the different priorities and wishes of Member States meeting in the Council. The Council concludes by inviting the Commission to present a progress report by June 2011 (Conclusion 2009).

The Parliament issued from the 2009 elections has maintained an active interest for the Arctic. In April 2010 it held a rather extensive debate on the EU policy on Arctic issues, with the participation of the High Representative and in January 2011 it accepted a resolution which had been prepared in autumn 2010 by Michael Gahler (PPE Group). At the same time an EU-Arctic Forum was initiated to provide MEPs with an open platform for debating and learning about Arctic issues; the European Parliament Intergroup on "Climate Change, Biodiversity and Sustainable Development" is in the process of establishing a sub-group with the Arctic as its main theme, intended to address all Arctic-relevant issues. Furthermore, in September 2010, the Parliament hosted the bi-annual meeting of Arctic parliamentarians.

In the Resolution on a sustainable EU policy for the High North (Resolution 2011) the European Parliament recalls that although the EU has no Arctic Ocean coastline so far, three European Union Member States - Denmark, Finland and Sweden - are Arctic States. The European Parliament reaffirms the legitimate interest of the EU and other countries as stakeholders by virtue of their rights and obligations under international law, its commitment to environmental, climate and other policies and its funding, research activities and economic interests, including shipping and exploitation of natural resources. This Conclusion also underlines that certain policies relevant to the Arctic, such as the conservation of marine biological resources under the common fisheries policy, are exclusive Union competences, while others are partly shared with Member States. The European Parliament also highlights that the EU is committed to devising its policy responses in the Arctic on the basis of the best available scientific knowledge and understanding of the 
processes affecting the Arctic, and is accordingly already devoting sizeable research efforts to generating sound scientific evidence to support its policy-making. It stresses the need for a united, coordinated EU policy on the Arctic region, in which both the EU's priorities and the potential challenges and a strategy are clearly defined (Resolution 2011).

\section{CONCLUSION}

In conclusion, it should be pointed out that the presented overview of the main EU documents in the area of the Arctic issues indicates that the EU policy towards the Arctic is closely related with perceiving the climate change in polar regions not only in terms of new possibilities, but also as sources of new threats for the international environment.

\section{REFERENCES}

Airoldi A., 2008, The European Union and the Arctic, Policies and Actions, Nordic Council of Ministers, Copenhagen.

Airoldi A., 2010, The European Union and the Arctic. Main developments: July 2008-July 2010, Nordic Council of Ministers, Copenhagen.

Arctic Climate Impact Assessment (ACIA), 2005, Arctic Climate Impact Assessment, Cambridge, Cambridge University Press.

Arctic Marine Shipping Assessment AMSA, 2009, Arctic Marine Shipping Assessment 2009 Report, Arctic Council, April 2009.

Busby J. W., 2007, Climate Change and National Security. An Agenda for Action, Council on Foreign Relation, Council Special Report No. 32.

Communication, 2008, The European Union and the Arctic Region, The European Commission.

Conclusion, 2009, Council conclusions on Arctic issues, 2985th Foreign Affairs Council meeting, Brussels, 8 December 2009.

GautierD.L.,BirdK.J.,CharpentierR.R.,GrantzA.,HouseknechtD.W.,KlettT.R., MooreT.E., Pitman J.K., Chenk Ch.J., Schuenemeyer J.H., Srrrensen K., Tennyson M.E., Valin Z.E., Wandrey C.J., 2009, Assessment of Undiscovered Oil and Gas in the Arctic, Science, $324,1175-1179$.

Giddens A., 2009, The Politics of Climate Change, Cambridge, Polity Press.

Heinämäki L., 2009, Rethinking the Status of Indigenous Peoples in International Environmental Decision-Making: Pondering the Role of Arctic Indigenous Peoples and the Challenge of Climate Change, [in:] Koivurova T., Caina E., Keskitalo H., Bankes N. (eds), Climate Governance in the Arctic, Springer, Berlin, 207-262.

Joint Paper, 2008, Joint Paper by the Commission and the Secretary-General/High Representative concerning Climate change and international security to the European Council, Brussels, 3 March 2008. 
Łuszczuk M., 2010, EU Arctic Policy in status nascendi, Studia Europejskie, 3, 85-110.

Resolution, 2008, European Parliament resolution of 9 October 2008 on Arctic governance.

Resolution, 2011, European Parliament resolution of 20 January 2011 on a sustainable EU policy for the High North. 